\title{
Metabolism of trans-2-Butene and Butane in Nocardia TB1
}

\author{
By C. G. VAN GINKEL, ${ }^{*}$ H. G. J. WELTEN, S. HARTMANS AND \\ J. A. M. DE BONT \\ Department of Microbiology, Agricultural University, Hesselink van Suchtelenweg 4. \\ 6703 CT Wageningen, The Netherlands
}

(Received 4 December 1986; revised 23 February 1987)

\begin{abstract}
A bacterium capable of growth on trans-2-butene was isolated from soil and identified as a Nocardia sp. The isolate also grew on propane, butane, pentane and hexane; gaseous and volatile 1-alkenes did not support growth. Intact cells grown on trans-2-butene or butane oxidized all n-alkanes, 1-alkenes, 2-alkenes and alcohols tested. Simultaneous adaptation studies, inhibitor experiments and measurements of enzyme activities in crude extracts indicated a degradative route of trans-2-butene via crotonic acid and of butane via butyric acid. The key enzymes in the proposed pathways were induced by growth on either trans-2-butene or butane. The induction of these enzymes and the substrate specificities of the enzymes suggest a relation between trans-2butene and butane degradation.
\end{abstract}

\section{INTRODUCTION}

Micro-organisms attack a wide range of saturated and unsaturated hydrocarbons (Klug \& Markovetz, 1971); the lower gaseous compounds are also readily degraded as originally shown by Tautz \& Donath (1930). Bacteria utilizing saturated gaseous hydrocarbons mainly belong to the genera Mycobacterium, Nocardia, Corynebacterium, Brevibacterium and Pseudomonas (Klug \& Markovetz, 1971), and most of these bacteria grow well on ethane, propane or butane (Hou et al., 1983; Patel et al., 1983; Philips \& Perry, 1974). In general, the pathway of alkane degradation proceeds via terminal hydroxylation of the alkane, yielding the corresponding primary alcohol (Klug \& Markovetz, 1971) but subterminal oxidations have also been demonstrated (Vestal \& Perry, 1969).

The ability of micro-organisms to grow on gaseous alkenes has been described for ethene (de Bont, 1976; Heyer, 1976), propene and 1-butene (de Bont et al., 1980; Cerniglia et al., 1976; van Ginkel \& de Bont, 1986), and for 1,3-butadiene (Watkinson \& Sommerville, 1976). The first intermediate in the metabolism of gaseous 1-alkenes is the corresponding 1,2-epoxyalkane formed by a monooxygenase (de Bont et al., 1979, 1983). The further metabolism of 1,2epoxyethane proceeds via acetyl-CoA (de Bont \& Harder, 1978), and the metabolism of 1,2epoxypropane presumably via a $\mathrm{C}_{2}+\mathrm{C}_{1}$ cleavage (Cerniglia et al., 1976).

A major difference between alkane- and alkene-grown bacteria is the substrate specificity towards gaseous hydrocarbons of the monooxygenases responsible for the initial oxygenation. Alkane monooxygenases from alkane-utilizers oxidize alkanes and l-alkenes (Hou et al., 1983; Patel et al., 1983) whereas the alkene monooxygenases are only able to epoxidate alkenes (Habets-Crützen et al., 1984; van Ginkel et al., 1986).

Knowledge on the metabolism of lower 2-alkenes, in contrast to the situation for 1-alkenes and alkanes, is scarce. Fujii et al. (1985) reported a 2-butene-utilizing Mycobacterium which was used in a microbial screening test. In this paper we report the isolation of a Nocardia sp. that can grow on trans-2-butene and butane, and the way in which it metabolizes these compounds.

\section{METHODS}

Chemicals. Gaseous alkenes and 1,2-epoxyethane were obtained from Hoek Loos. trans-2-Butene was obtained from Hicol. NADH was purchased from Boehringer. All other chemicals were obtained from Janssen Chimica. 
Micro-organisms. Nocardia TBI was isolated essentially as described by de Bont (1976) except that ethene was replaced by trans-2-butene. Nocardia vaccinii was a gift from Dr D. Jones, Department of Microbiology, Leicester University, UK.

Cultivation. The micro-organisms were cultivated in mineral salts medium supplemented with trans-2-butene or butane as described by Wiegant \& de Bont (1980). Growth on different carbon sources was determined in $100 \mathrm{ml}$ Erlenmeyer flasks containing $10 \mathrm{ml}$ mineral salts medium supplemented with the appropriate carbon source. The concentration of gaseous hydrocarbons was set by injecting the gas in a known volume. The concentration of the gaseous substrates supplied was about $5 \%(\mathrm{v} / \mathrm{v})$ while the concentration of the other carbon sources was $0.2 \%$ $(\mathrm{w} / \mathrm{v})$.

Analyses. Determination of gaseous alkenes and 1,2-epoxyalkanes was described by de Bont et al. (1979). $\mathrm{CO}_{2}$ was measured as described by de Bont et al. (1983). Acids were measured with a Varian Aerograph series 2400 gas chromatograph fitted with a Chromosorb 101 ( 80 to 100 mesh) column; the column temperature was $190^{\circ} \mathrm{C}$ and the carrier gas was $\mathrm{N}_{2}$ saturated with formic acid. Total organic carbon was determined with a Dohrmann type DC organic carbon analyser. Dissolved $\mathrm{O}_{2}$ concentrations were measured at $30^{\circ} \mathrm{C}$ with a Yellow Springs model 53 monitor equipped with a polarographic sensor. Protein concentrations of washed cell suspensions and cell-free extracts were determined as described by Habets-Crützen et al. (1984). Mycolic acids were determined as described by Minnikin et al. (1975).

Determination of the doubling times. This was done by optical density measurements as described by HabetsCrützen et al. (1984).

Preparation of washed cell suspensions and cell-free extract. This was described by de Bont et al. (1979).

Oxidation of hydrocarbons and epoxyalkanes. The oxidation of hydrocarbons and the excretion of epoxyalkanes by washed cell suspensions $(2.5 \mathrm{ml})$ were measured by incubating the cells in $50 \mathrm{mM}$-sodium/potassium phosphate buffer $(\mathrm{pH} 7.0)$ at $30^{\circ} \mathrm{C}$ in Hungate tubes. The appropriate gas $(0.075 \mathrm{ml})$ or $0.1 \mathrm{ml}$ of a $10 \mathrm{~mm}$-epoxyalkane solution were injected into the Hungate tubes. Samples from the gas phase were withdrawn at regular intervals and analysed for hydrocarbons and epoxyalkanes.

Enzyme activities. Hydrocarbon monooxygenases (EC 1.14.13.-) were measured as described by de Bont \& Harder (1978) except that ethene was replaced by trans-2-butene or butane. For crotonic alcohol dehydrogenase (EC 1.1.1.1), crotonic aldehyde dehydrogenase (EC 1.2.1.3) and butanal dehydrogenase (EC 1.2.1.3), the reaction mixture $(3 \mathrm{ml})$ contained $3 \mu \mathrm{mol}$ alcohol or aldehyde, $3 \mu \mathrm{mol} \mathrm{NAD}$ and $130 \mu \mathrm{mol} \mathrm{Tris} / \mathrm{HCl}$ buffer (pH 8.5); the change in $A_{340}$ due to NAD reduction was followed. Butanal reductase (EC 1.1.1.1) was assayed by following NADH oxidation. The reaction mixture $(1 \mathrm{ml})$ contained $130 \mu \mathrm{mol}$ sodium/potassium phosphate buffer (pH 7.0), $0.6 \mu \mathrm{mol}$ NADH and the reaction was started by adding $3 \mu \mathrm{mol}$ butanal. Thiokinases (EC 6.2.1.-) were assayed by following the formation of a hydroxamic acid complex which was measured as the increase in $A_{540}$. The reaction mixture $(1 \mathrm{ml})$ contained $40 \mu \mathrm{mol}$ Tris $/ \mathrm{HCl}(\mathrm{pH} 7), 10 \mu \mathrm{mol} \mathrm{MgCl}_{2}, 2.5 \mu \mathrm{mol} \mathrm{ATP}, 0.5 \mu \mathrm{mol} \mathrm{CoA}$, $200 \mu \mathrm{mol}$ hydroxylamine, $10 \mu \mathrm{mol}$ crotonic acid or butyric acid and the reaction was stopped after $30 \mathrm{~min}$ by adding $1 \mathrm{ml}$ of a solution of $12 \%(\mathrm{v} / \mathrm{v}) 3 \mathrm{M}-\mathrm{HCl}$ and $5 \%(\mathrm{v} / \mathrm{v}) \mathrm{TCA}$ in $0.1 \mathrm{M}-\mathrm{HCl}$. The absorption coefficient used was $6411 \mathrm{~mol}^{-1} \mathrm{~cm}^{-1}$ (Beinert et al., 1953). Acetoacetyl-CoA thiolase (EC 2.3.1.9) (Senior \& Dawes, 1973) and isocitrate lyase (EC 4.1.3.1) (Dixon \& Kornberg, 1959) were assayed as previously described.

$\mathrm{CO}_{2}$ production from crotonic alcohol and 2,3-epoxybutane. Washed cell suspensions of trans-2-butene-grown cells were incubated in $50 \mathrm{ml}$ screw-cap bottles at $30^{\circ} \mathrm{C}$ with $0 \cdot 4 \%(\mathrm{v} / \mathrm{v})$ trans-2-butene in the gas phase, $0 \cdot 2 \mathrm{~mm}-2,3-$ epoxybutane or $0.2 \mathrm{mM}$-crotonic alcohol. $\mathrm{CO}_{2}$ production was followed by measuring the $\mathrm{CO}_{2}$ concentration in the gas phase at regular intervals.

Inhibition studies. Washed cell suspensions of trans-2-butene- and butane-grown Nocardia TB1 were incubated at $30^{\circ} \mathrm{C}$ with $5 \mathrm{~mm}$-arsenite or $100 \mathrm{~mm}$-fluoroacetate in screw-cap bottles $(50 \mathrm{ml})$. trans-2-Butene or butane was injected into the bottles and the change in the concentration of trans-2-butene or butane was measured. Any accumulation of acids was also measured by gas chromatography, using samples of the supernatant fluid collected after centrifugation. Washed cells of trans-2-butene-grown Nocardia TB1 were incubated at $30^{\circ} \mathrm{C}$ in $50 \mathrm{ml} \mathrm{screw-}$ cap bottles. 2,3-Epoxybutane $(2.5 \mu \mathrm{mol})$ was injected and the oxidation rate of the epoxide was measured. Inhibition of the oxidation rate by trans-2-butene was measured after $17 \mathrm{~min}$ by injecting various amounts of trans2-butene into the screw-cap bottles.

\section{RESULTS}

\section{Isolation and characterization}

A bacterium capable of growth on trans-2-butene was enriched by incubating a sample of ditch water in the presence of trans-2-butene. From this enrichment a red-pigmented Grampositive bacterium was isolated, which produced leathery, dry and crusty colonies when growing on a solid mineral salts medium with trans-2-butene in the gas phase as carbon and energy source. Aerial hyphae were not produced by this strain. The bacterium formed a branched 
Table 1. Oxidation of various hydrocarbons by washed cell suspensions of trans-2-butene- and butane-grown Nocardia TBI

$\begin{array}{lcc}\text { Substrate } & \begin{array}{l}\text { Activity [nmol } \text { min }^{-1} \text { (mg } \\ \text { protein) }\end{array} & \overbrace{\text { trans-2-Butene }}^{-1} \text { after } \\ \text { Methowth on: }\end{array}$

mycelium typical of Nocardia spp. On mycolic acid analysis, the methanolysate of the isolated strain showed the same pattern as that of Nocardia vaccinii. The bacterium was able to grow on several substrates including phenol, dextran, acetate, propionate, butyrate, ethanol, 1-propanol, 1-butanol, 2-butanol, glucose and $\mathrm{H}_{2} / \mathrm{CO}_{2}$, but not on methanol. It reduced nitrate to nitrite but did not hydrolyse gelatine or xanthine. On the basis of the above characteristics the organism was tentatively classified as a Nocardia sp.

Nocardia TB1 is the first bacterium isolated on trans-2-butene and therefore it was of interest to determine which gaseous and volatile hydrocarbons could serve as a growth substrate. This strain was able to grow on the saturated hydrocarbons propane, butane, pentane, hexane and hexadecane but not on methane and ethane. The unsaturated hydrocarbons ethene, propene, 1-butene, 1,3-butadiene, 1-pentene and 1-hexene were not growth substrates. Growth on cis-2-butene was very slow. Culture doubling times of the isolated strain on butane and trans-2butene were 6 and $30 \mathrm{~h}$, respectively.

\section{Oxidation of hydrocarbons by trans-2-butene- and butane-grown Nocardia TBI}

Washed cell suspensions of trans-2-butene-grown Nocardia TB1 were able to oxidize all gaseous n-alkanes tested except methane (Table 1). Gaseous 1-alkenes were also oxidized, but the oxidizing activity levelled off after a short period of time when the corresponding 1,2epoxyalkanes accumulated to a concentration of approximately $0.25 \mathrm{~mm}$. From ethene and propene, the 1,2-epoxyalkanes were formed in stoichiometric amounts but from 1-butene only $50 \%$ was transformed into 1,2-epoxybutane whereas an unknown product was formed from the remainder. No epoxyalkanes accumulated from either trans-2-butene or cis-2-butene. Butanegrown cells oxidized the hydrocarbons tested twice as fast as trans-2-butene-grown cells but at otherwise similar relative rates (Table 1); the substrate oxidation rates also levelled off when 1,2epoxyalkanes accumulated.

\section{Inhibition studies with Nocardia TBI}

Experiments to detect the products of butane and trans-2-butene oxidation were done with whole cells, using different possible product analogues of the first oxidation reactions. Alcohols and epoxides that may compete for the active site of the second enzyme in the degradative pathway of these hydrocarbons did not act as inhibitors. However, using the nonspecific enzyme inhibitor arsenite, it was possible to detect butyric acid and crotonic acid as possible intermediates of butane and trans-2-butene metabolism respectively (Fig. 1). Similar results were obtained using fluoroacetate as an inhibitor.

\section{Substrate-dependent oxygen uptake}

Substrate-dependent oxygen uptake was determined for trans-2-butene-, butane-, and succinate-grown cells (Table 2). Crotonic alcohol and 2,3-epoxybutane stimulated oxygen 


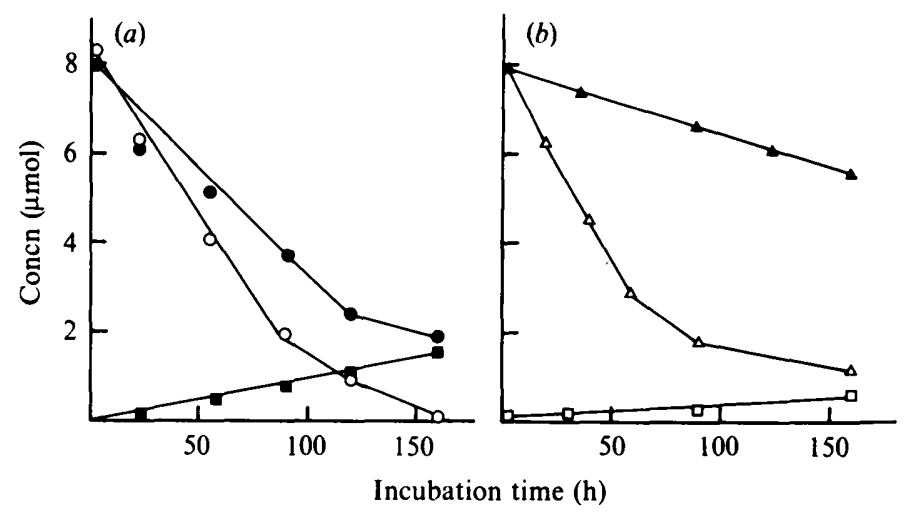

Fig. 1. Effect of $5 \mathrm{mM}$-arsenite on the accumulation of intermediates by washed cell suspensions of Nocardia TB1 grown on either (a) butane (14.5 mg protein) or (b) trans-2-butene (17 mg protein). Incubations with arsenite: $\boldsymbol{O}$, butane; $\boldsymbol{\Delta}$, trans-2-butene; $\square$, crotonic acid; $\boldsymbol{\square}$, butyric acid. Incubations in the absence of arsenite: $O$, butane; $\triangle$, trans-2-butene.

Table 2. Increase in the rate of oxygen uptake by washed cell suspensions of Nocardia TBI grown on various substrates

The endogenous rate of oxygen uptake by trans-2-butene-, butane- and succinate-grown cells was 13,12 and $32 \mathrm{nmol} \mathrm{min}^{-1}$ (mg protein) $)^{-1}$, respectively.

\begin{tabular}{|c|c|c|c|}
\hline \multirow[b]{2}{*}{ Substrate } & \multicolumn{3}{|c|}{$\begin{array}{c}\left.\text { Activity [nmol } \min ^{-1}(\mathrm{mg} \text { protein })^{-1}\right] \text { after } \\
\text { growth on: }\end{array}$} \\
\hline & trans-2-Butene & Butane & Succinate \\
\hline trans-2-Butene & 64 & 112 & 0 \\
\hline cis-2-Butene & 60 & 105 & 0 \\
\hline Crotonic alcohol & 64 & 103 & 0 \\
\hline Crotonic aldehyde & 80 & 102 & 12 \\
\hline Crotonic acid & 63 & 63 & 19 \\
\hline Butane & 46 & 53 & 0 \\
\hline 1-Butanol & 51 & 75 & 5 \\
\hline 2-Butanol & 19 & 28 & 0 \\
\hline Butanal & 70 & 80 & 11 \\
\hline Butanone & 12 & 38 & 5 \\
\hline Butyrate & 31 & 52 & 19 \\
\hline 3-Hydroxybutyrate & 19 & 11 & 3 \\
\hline Acetate & 57 & 48 & 32 \\
\hline 2,3-Epoxybutane & 18 & 16 & 0 \\
\hline Succinate & 7 & 3 & 83 \\
\hline
\end{tabular}

uptake by butane- and trans-2-butene-grown cells whereas the oxygen uptake by succinategrown cells was not stimulated by these substrates. Respiration of butane-grown cells (as compared to the endogenous respiration) was increased by 1-butanol and 2-butanol. 1-Butanol and 2-butanol did not enhance or only slightly enhanced the respiration rate of succinate-grown cells. Other possible intermediates in the degradative pathways of trans-2-butene and butane tested enhanced the oxygen uptake of trans-2-butene- as well as butane- and succinate-grown cells (Table 2).

\section{Enzyme activities}

The nature of the enzyme system involved in the attack on butane or trans-2-butene was investigated by measuring the disappearance of butane or trans-2-butene using cell-free extracts. Activity was only observed when $\mathrm{NAD}(\mathrm{P}) \mathrm{H}$ and molecular oxygen were included in the reaction mixture, indicating that a monooxygenase is probably responsible for the oxidation of these hydrocarbons (Table 3). 
Table 3. Specific activities of enzymes in cell-free extracts of Nocardia TB1 grown on trans-2-butene, butane and succinate

\begin{tabular}{l}
\multicolumn{1}{c}{ Enzyme } \\
trans-2-Butene monooxygenase* \\
Butane monooxygenase* \\
Crotonic alcohol dehydrogenase $†$ \\
1-Butanol dehydrogenase $\dagger$ \\
Butanal reductase* \\
Crotonic aldehyde dehydrogenase $†$ \\
Butanal dehydrogenase $\dagger$ \\
Crotonic acid thiokinase $\ddagger$ \\
2-Butanol dehydrogenase $\dagger$ \\
Butyric acid thiokinase $\ddagger$ \\
Thiolase
\end{tabular}

- Requirement for NADH

$†$ Requirement for NAD

$\ddagger$ Requirement for coenzyme A

Activity [nmol $\mathrm{min}^{-1}(\mathrm{mg} \text { protein })^{-1}$ ] after growth on:

$\overbrace{\text { trans-2-Butene Butane Succinate }}$

$\begin{array}{rrr}2 & 2 & 0 \\ 1 & 1 & 0 \\ 9 & 20 & 0 \\ 0 & 0 & 0 \\ 25 & 12 & 18 \\ 3 & 5 & 0 \\ 12 & 76 & 3 \\ 12 & 17 & 10 \\ 5 & 5 & 4 \\ 15 & 9 & 10 \\ 154 & 153 & 150\end{array}$

Table 4. Isocitrate lyase activity in cell-free extracts of Nocardia TBI after growth on various substrates

$\begin{array}{lc}\text { Growth substrate } & \text { Activity [nmol } \mathrm{min}^{-1}(\mathrm{mg} \text { protein })^{-1} \text { ] } \\ \text { Acetate } & 417 \\ \text { Propionate } & 3 \\ \text { Butyrate } & 220 \\ \text { Succinate } & 1 \\ \text { trans-2-Butene } & 110 \\ \text { Butane } & 137 \\ \text { 1-Butanol } & 171 \\ \text { 2-Butanol } & 1\end{array}$

Crotonic alcohol dehydrogenase and crotonic aldehyde dehydrogenase were induced after growth on trans-2-butene or butane and a 1-butanol dehydrogenase, measured as 1-butanal reductase, was also induced in butane- and trans-2-butene-grown cells. 2-Butanol dehydrogenase was also present but was constitutive (Table 3). Thiokinases were induced in trans-2-butene-, butane- and succinate-grown cells and the requirement of the enzyme for CoA and ATP was shown by omitting these cofactors from the assay mixture. Finally, it was shown that acetoacetyl-CoA thiolase was present in trans-2-butene-, butane- and succinate-grown cells (Table 3).

Evidence that butane is hydroxylated at $\mathrm{C}_{1}$ was also obtained by comparing isocitrate lyase activity in Nocardia TB1 after growth on various carbon sources (Table 4). Growth on butane and 1-butanol resulted in the induction of isocitrate lyase, whereas 2-butanol-grown cells contained no isocitrate lyase activity.

\section{The fate of trans-2,3-epoxybutane}

trans-2,3-Epoxybutane was oxidized by butane- and trans-2-butene-grown Nocardia TB1 (Table 2). The oxidation of cis-2,3-epoxybutane was not investigated because this compound was not available. trans-2,3-Epoxybutane oxidation by a washed cell suspension of trans-2butene-grown cells was inhibited by trans-2-butene, indicating that the monooxygenase present in Nocardia TB1 was probably responsible for the oxidation of trans-2,3-epoxybutane. trans-2,3Epoxybutane was not oxidized to $\mathrm{CO}_{2}$ because from this substrate hardly any additional $\mathrm{CO}_{2}$ was formed as compared to the amount of $\mathrm{CO}_{2}$ formed endogenously, whereas washed cell suspensions of trans-2-butene-grown Nocardia TB1 produced twice the amount of $\mathrm{CO}_{2}$ formed 
during the endogenous respiration when oxidizing trans-2-butene or crotonic alcohol. Organic carbon derived from an unknown oxidation product accumulated in the supernatant during 2,3epoxybutane oxidation by washed cell suspensions of trans-2-butene-grown Nocardia TB1, whereas during growth on trans-2-butene no organic carbon could be detected in the mineral salts medium.

\section{DISCUSSION}

Nocardia TB1 was isolated with trans-2-butene as carbon and energy source and also grew on several saturated, straight-chain hydrocarbons but not on 1-alkenes. Micro-organisms that grow on both saturated and unsaturated gaseous hydrocarbons have been reported i.e. Mycobacterium E20 (de Bont et al., 1979) and a Nocardia sp. (Fujii et al., 1985) but most hydrocarbon-utilizing bacteria cannot grow on both saturated and unsaturated hydrocarbons (Lukins \& Foster, 1963; Habets-Crützen et al., 1984; van Ginkel et al., 1986). Both trans-2-butene- and butane-grown cells of Nocardia TB1 oxidized a wide range of hydrocarbons (Table 1), but this capacity to oxidize such a wide range of substrates is not unique. Alkane-utilizing micro-organisms are capable of hydroxylation and epoxidation reactions (Hou et al., 1983; Patel et al., 1983), whereas 1-alkene-utilizing bacteria can only epoxidate double bonds and do not hydroxylate saturated hydrocarbons (de Bont et al., 1979; van Ginkel \& de Bont, 1986). Considering the capacity of trans-2-butene-grown cells to oxidize saturated hydrocarbons, it would seem likely that these cells contain an alkane-type monooxygenase with broad substrate specificity, and not a 1-alkene-type monooxygenase.

It was possible to detect monooxygenase activity in extracts of trans-2-butene-grown cells, and the activity could theoretically result in the formation of either crotonic alcohol or 2-butanone as a result of hydroxylation activity, or in the formation of 2,3-epoxybutane as a result of epoxidation activity of the monooxygenase similar to the results of Hou et al. (1983).

1,2-Epoxyethane and 1,2-epoxypropane were not oxidized by trans-2-butene-grown cells whereas 1,2-epoxybutane and especially 2,3-epoxybutane were oxidized, which might indicate that trans-2-butene is metabolized via 2,3-epoxybutane. On the other hand, substrate specificity towards unsaturated and saturated hydrocarbons indicated that trans-2-butene is metabolized via a hydroxylation reaction. Moreover, results with washed cell suspensions of trans-2-butenegrown Nocardia TBl showed that 2,3-epoxybutane is not oxidized to $\mathrm{CO}_{2}$ but to an unidentified product whereas the other possible intermediate crotonic alcohol, and trans-2-butene itself, were both oxidized to $\mathrm{CO}_{2}$. Indeed, it was shown that washed cells grown on trans-2-butene excreted a product during the oxidation of 2,3-epoxybutane and that this product probably originates from a hydroxylation reaction by the monooxygenase.

Washed cell suspensions of trans-2-butene-grown cells inhibited with fluoroacetate or arsenite excreted crotonic acid, which is an oxidation product of crotonic alcohol, and crotonic alcohol dehydrogenase and crotonic aldehyde dehydrogenase were induced in trans-2-butene-grown cells (Table 3). From these results we conclude that trans-2-butene is metabolized via an initial hydroxylation at the $C_{1}$ position rather than via an initial epoxidation reaction.

It was also possible to detect monooxygenase activity in butane-grown cells (Table 3). Hydroxylation of butane could result either in 1-butanol or in 2-butanol. The isocitrate lyase activities suggest that butane is hydroxylated terminally (Table 4). Further evidence for the hydroxylation of butane at the $\mathrm{C}_{1}$ position was obtained from inhibition studies with arsenite. Butyric acid was excreted by butane-grown cells during the oxidation of butane in the presence of an inhibitor (Fig. 1). In cell-free extracts of butane-grown cells, butanal reductase activity was measured (Table 3).

The further metabolism of trans-2-butene and butane proceeds via $\beta$-oxidation as determined by thiokinase and acetoacetyl-CoA thiolase activities (Table 3 ).

Growth of Nocardia TB1 on cis-2-butene was very slow as compared to growth on trans-2butene although both isomers of 2-butene were oxidized by trans-2-butene- and butane-grown cells at comparable rates (Tables 1 and 2). The metabolism of the cis-isomer was not further investigated because isomers of crotonic alcohol, crotonic aldehyde and crotonic acid were not available. 


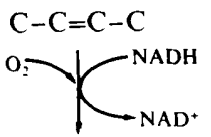<smiles>CC1CCC(C)(C[N+](=O)[OH2+])C(C)C1[N+](=O)[O-]</smiles>

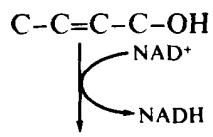

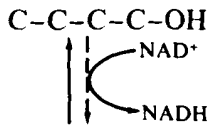

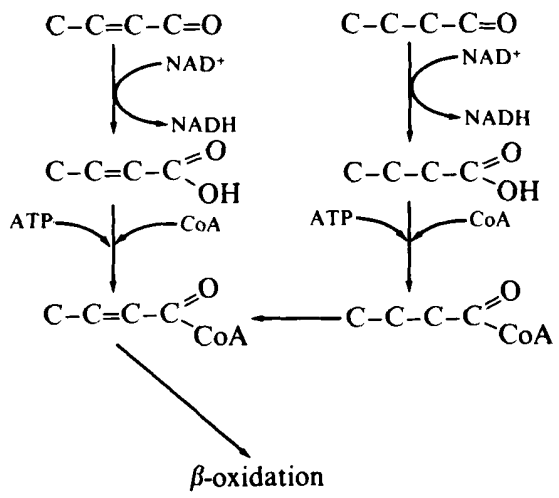

Fig. 2. Proposed degradation pathways of trans-2-butene and butane in Nocardia TB1.

On the basis of the results obtained in this study we propose pathways for the metabolism of butane and trans-2-butene in Nocardia TB1 as shown in Fig. 2. From our experiments it seems very likely that trans-2-butene degradation is catalysed by the same enzymes as butane degradation because substrate specificities (Tables 1 and 2) are comparable and enzymes induced in butane- and trans-2-butene-grown cells are able to oxidize the intermediates of both pathways.

We are indebted to Professor Dr W. Harder and Professor Dr C. J. E. A. Bulder for advice and helpful discussions in preparing the manuscript.

\section{REFERENCES}

Beinert, H., Green, D. E., Hele, P., Hift, H., von KORF, R. W. \& Ramakrishnan, C. W. (1953). The acetate activating enzyme system of heart muscle. Journal of Biological Chemistry 203, 35-45.

DE BONT, J. A. M. (1976). Oxidation of ethylene by soil bacteria. Antonie van Leeuwenhoek 42, 59-71.

DE BONT, J. A. M. \& HARDER, W. (1978). Metabolism of ethylene by Mycobacterium E20. FEMS Microbiology Letters 3, 89-93.

de Bont, J. A. M., Attwood, M. M., Primrose, S. B. \& HARDER, W. (1979). Epoxidation of short-chain alkenes in Mycobacterium E20; the involvement of a specific mono-oxygenase. FEMS Microbiology Letters 3, 89-93.

De Bont, J. A. M., Primrose, S. B., Collins, M. D. \& JONEs, D. (1980). Chemical studies on some bacteria which utilize gaseous unsaturated hydrocarbons. Journal of General Microbiology 117, 97-102.

De Bont, J. A. M., van Ginkel, C. G., Tramper, J. \& LUYBen, K. Ch. A. M. (1983). Ethylene oxide production by immobilized Mycobacterium Pyl in a gas/solid bioreactor. Enzyme and Microbial Technology 5, 55-60.
Cerniglia, C. E., Blevins, W. T. \& Perry, J. J. (1976). Microbial oxidation and assimilation of propylene. Applied and Environmental Microbiology 6, 764-768.

DiXoN, G. H. \& KornberG, H. L. (1959). Assay methods for the key enzymes of the glyoxylate cycle. Biochemical Journal 72, 3p.

FujII, T., OGawa, T. \& FukUdA, H. (1985). A screening system for microbes which produce olefin hydrocarbons. Agricultural and Biological Chemistry 49, 651-657.

van Ginkel, C. G. \& DE Bont, J. A. M. (1986). Isolation and characterization of alkene-utilizing Xanthobacter spp. Archives of Microbiology 145, 403407.

van Ginkel, C. G., Welten, H. G. J. \& De Bont, J. A. M. (1986). Epoxidation of alkenes by alkenegrown Xanthobacter spp. Applied Microbiology and Biotechnology 24, 334-337.

Habets-Crützen, A. Q. H., Brink, L. E. S., van Ginkel, C. G., de Bont, J. A. M. \& Tramper, J. (1984). Production of epoxides from gaseous alkenes by resting-cell suspensions and immobilized cells of 
alkene-utilizing bacteria. Applied Microbiology and Biotechnology 20, 245-251.

HeYer, J. (1976). Mikrobielle Verwertung von Äthylen. Zeitschrift für allgemeine Mikrobiologie 16, 633637.

Hou, C. T., Patel, P., Laskin, A. I., Barnabe, N. \& BARIST, I. (1983). Epoxidation of short-chain alkenes by resting-cell suspensions of propane-grown bacteria. Applied and Environmental Microbiology 46, 171-177.

KLUG, M. J. \& MARKOVETZ, A. J. (1971). Utilization of aliphatic hydrocarbons by micro-organisms. Advances in Microbial Physiology 5, 1-39.

LUKINS, H. B. \& FosteR, J. W. (1963). Utilization of hydrocarbons and hydrogen by mycobacteria. Zeitschrift für allgemeine Mikrobiologie 3, 251-264.

Minnikin, D. E., Alshamaony, L. \& Goodfellow, M. (1975). Differentiation of Mycobacterium, Nocardia and related taxa by thin layer chromatographic analysis of whole organism methanolysates. Journal of General Microbiology 88, 200-204.

PATel, R. N., Hou, C. T., Laskin, A. I., Felix, A. \& Derelanko, P. (1983). Epoxidation of n-alkenes by organisms grown on gaseous alkanes. Journal of Applied Biochemistry 5, 121-131.
Philips, W. E. \& Perry, J. J. (1974). Metabolism of n-butane and 2-butanone by Mycobacterium vaccae. Journal of Bacteriology 120, 987-989.

SENIOR, P. J. \& DAWES, E. A. (1973). The regulation of poly- $\beta$-hydroxybutyrate in Azotobacter beijerinckii. Biochemical Journal 134, 225-238.

Tautz, J. \& Donath, P. (1930). Uber die Oxydation des Wasserstofs und Kohlenwasserstoffe mittels Bacterien. Zeitschrift für physiologische Chemie 190, 141-168.

Vestal, J. R. \& Perry, J. J. (1969). Divergent metabolic pathways for propane and propionate utilisation by a soil isolate. Journal of Bacteriology 99 , 216-221.

Watkinson, R. J. \& Somerville, H. J. (1976). The microbial utilization of butadiene. In Proceedings of the International Biodegradation Symposium, no. 3, pp. 35-42. Edited by J. M. Sharply \& J. A. M. Kaplan. Kingston, Rhode Island, USA : Applied Science.

WiEgANT, W. M. \& DE BoNT, J. A. M. (1980). A new route for ethylene glycol metabolism in Mycobacterium E44. Journal of General Microbiology 120, 325-331. 